\title{
Ammonia-based Solid Oxide Fuel Cell for zero emission maritime power: a case study.
}

\author{
Simona Di Micco ${ }^{1,}$, Mariagiovanna Minutillo $^{2}$, Luca Mastropasqua ${ }^{3}$, Viviana Cigolotti, ${ }^{4}$ Jack $_{\text {Brouwer }}{ }^{3}$ \\ ${ }^{1}$ Univerisity of Naples "Parthenope", Naples, Italy \\ ${ }^{2}$ Department of Industrial Engineering, University of Salerno, Salerno, Italy \\ ${ }^{3}$ National Fuel Cell Research Center, University of California, Irvine, CA 92697-3550, United States \\ ${ }^{4}$ ENEA - Italian National Agency for New Technologies, Energy and Sustainable Economic Development, Naples, Italy
}

\begin{abstract}
Implementing environmentally friendly fuels and high efficiency propulsion technologies to replace the Internal Combustion Engine (ICE) fueled by fossil fuels such as Heavy Fuel Oil (HFO) and Marine Gas Oil (MGO) on board ships represents an attractive solution for maritime power. In this context, fuel cells can play a crucial role, thanks to their high energy efficiency and ultra-low to zero criteria pollutant emissions and environmental impact.

This paper performs the technical feasibility analysis for replacing the conventional diesel engine powertrain on board a commercial vessel with an innovative system consisting of ammonia-fuel-based Solid Oxide Fuel Cell (SOFC) technology.

Taking into account the size of the diesel engines installed on board and the typical cruise performed by the commercial vessel, the ammonia consumption, as well as the optimal size of the innovative propulsion system have been assessed. In particular, the SOFC powertrain is sized at the same maximum power output as the main reference diesel engine. The mass and energy balances of the ammonia-based SOFC system have been performed in Aspen Plus ${ }^{\mathrm{TM}}$ environment. The gravimetric $\left(\mathrm{kWh} \mathrm{kg}^{-1}\right)$ and volumetric $\left(\mathrm{kWh} \mathrm{m}^{-3}\right)$ energy density features of the ammonia storage technology as well as the weight and volume of the proposed propulsion system are evaluated for verifying the compliance with the ship's weight and space requirements. Results highlight that the proposed propulsion system involves an increase in weight both in the engine room and in the fuel room compared to the diesel engine and fuel. In particular, a cargo reduction of about $2.88 \%$ is necessary to fit the ammonia-based SOFC system compared to the space available in the reference dieselfueled ship.
\end{abstract}

\section{Introduction}

Maritime transport is one of the largest greenhouse gas (GHG) emitting sectors of the global economy, responsible for around $1 \mathrm{Gt}$ of $\mathrm{CO}_{2, \text { eq }}$ every year $[1,2]$. It is responsible for $10-15 \%$ of anthropogenic sulfur $\left(\mathrm{SO}_{\mathrm{x}}\right)$ and nitrogen oxide $\left(\mathrm{NO}_{\mathrm{x}}\right)$ emissions, as well as approximately $3 \%$ of the carbon dioxide $\left(\mathrm{CO}_{2}\right)$ emissions [3]. The stringent demands by the national and international authorities to reduce the environmental footprints of the shipping industry have pushed the industry towards the use and adoption of cleaner power sources as well as alternative fuels. As matter fact, the International Maritime Organization (IMO) has set ambitious goals to reduce, and eventually eliminate, greenhouse gas (GHG) emissions from international shipping [4]. Decarbonizing the maritime sector involves changes in onboard energy storage and in energy conversion systems. Therefore, the introduction of innovative technologies as well as of carbon-free fuels both on ships and in ports, can pave the way for reducing the emissions [5-8].
In this regard, new energy conversion technologies such as fuel cells can represent the key element for the decarbonization in the maritime sector [9-12]. Several studied demonstrated the viability of using $\mathrm{FCs}, \mathrm{H}_{2}$ and $\mathrm{H}_{2}$ carriers in oceanic going vessels (OGVs).

Demonstration projects are underway to highlight the viability of $\mathrm{H}_{2}$ and $\mathrm{H}_{2}$ carriers to power ships using FCs.

The METHAPU [13] (Methanol auxiliary power unit) project foresees the implementation of a $20 \mathrm{~kW}$ SOFC (solid oxide fuel cell) system fed by methanol on board a Roll-on/Roll-off (RoRo) vessel. The SOFC system comprised a methanol tank, a reformer, the SOFC stack, a catalytic combustion afterburner and in-process heat exchangers.

The FELICITAS project [14], foresees to develop and to test a $250 \mathrm{~kW}$ LNG-powered stationary SOFC system. In addition, the coupling of SOFC system with a gas turbine and the heating, ventilation and air conditioning systems is examined.

The E4Ships SchIBZ project [15] studies a hybrid power system combining a $50 \mathrm{~kW}$ containerized SOFC unit with lithium-ion battery packs. It is developed for the auxiliary

\footnotetext{
*orresponding author: $\underline{\text { simona.dimicco@studenti.uniparthenope.it }}$
} 
power supply onboard the general cargo ship MS Forester. The hybrid power system consists of a diesel tank, a water tank, a reformer, the SOFC stack, a catalytic combustor and lithium-ion battery packs to compensate the fluctuations of the electrical loads and power electronics. Several studies available in literature analyze the possibility of installing fuel cells on board ships.

Dall'Armi et al. [16], proposed a process simulation study to analyze the peak shaving services that a hybrid $\mathrm{PEMFC} / \mathrm{Li}$-ion battery propulsion system can provide to a small RoRo vessel and to a passenger ferry. They also evaluated different compressed hydrogen storage solutions depending on the cruise duration.

Di Micco et al. [17] developed a techno-economic feasibility analysis for integrating a polymer electrolyte membrane fuel cell (PEMFC) technology on board Ro-Pax ferry, considering two different hydrogen storage technologies $\left(\mathrm{GH}_{2}\right.$ and $\left.\mathrm{LH}_{2}\right)$. Results highlighted that, although both the hydrogen solutions were suitable in terms of weight and volume, the number of voyages (without refueling) were drastically reduced.

Strazza et al. [18] analyzed the methanol-fueled SOFCs as an on-board auxiliary system.

Gianni et al. [19] analyzed the possibility to install PEMFC and SOFC onboard a cruise vessel. They observed that the installation of PEMFC or SOFC systems, involves an increase of the space in engine and fuel rooms.

De Baldasano et al. [20] investigated a hybrid plant based on diesel engine and methane fueled SOFCs for an offshore support vessel, where the fuel cell unit is used during slow cruising operations and feature a power output four times smaller compared to the main engine.

Haseltalab et al. [21] developed a new approach to enable the use of SOFC fed by Liquid Natural Gas (LNG) as the main power source on board vessels. Results demonstrated that the integration of the SOFC with the propulsion system allowed to yield up to $53 \% \mathrm{CO}_{2}$ reduction and $21 \%$ higher fuel utilization efficiency compared to conventional diesel-electric vessels.

According to this background, it is possible to perceive the great interest in developing fuel cell-based powertrain system on board ships, even if several issues, from technical and economic points of view, must be further analyzed in depth.

In this work, the technical feasibility replacement analysis of a conventional diesel engine powertrain with an innovative power system consisting of ammonia-based SOFC technology, is presented. The analysis is carried out by comparing the two powertrain solutions in terms of volumes and weights onboard a commercial vessel.

The system design and the energy balance assessment are performed by using a simulation model developed in Aspen Plus ${ }^{\mathrm{TM}}$ environment.

\section{Vessel description and operation}

The selected commercial vessel is equipped with a 8.3 MW main engine (ME) and 2.8 MW auxiliary engines (AEs) [22,23]. During the navigation the load demand is approximately constant and the auxiliary engines are used for docking/in-port operation and for satisfying the electric demand. Table 1 shows the general characteristics of the target vessel and Table 2 lists the volume and weight of the engines currently installed on board.

Table 1. General characteristics of the target vessel [24]

\begin{tabular}{|l|c|}
\hline Engine Room Volume $\left(\mathrm{m}^{3}\right)$ & $3,276.0$ \\
\hline Engines Weight (ton) & 107.1 \\
\hline Fuel Room Volume $\left(\mathrm{m}^{3}\right)$ & $1,646.0$ \\
\hline Fuel Room Mass Capacity (ton) & $1,374.4$ \\
\hline
\end{tabular}

Table 2. Diesel engine system technical characteristics

\begin{tabular}{|l|c|c|}
\hline Equipment & $\begin{array}{c}\text { Volume } \\
\left(\mathrm{m}^{3}\right)\end{array}$ & $\begin{array}{c}\text { Weight } \\
\text { (tons) }\end{array}$ \\
\hline Main Diesel Engine [25,26] & 140.4 & 84.9 \\
\hline $\begin{array}{l}\text { Auxiliary Diesel Engines } \\
{[26,27]}\end{array}$ & 17.6 & 22.2 \\
\hline Total & 158.0 & 107.1 \\
\hline
\end{tabular}

Fig. 1 depicts the vessel load profile as percentage of the operating power compared to the total installed power during its typical cruise, which has a duration of about 240 hours.

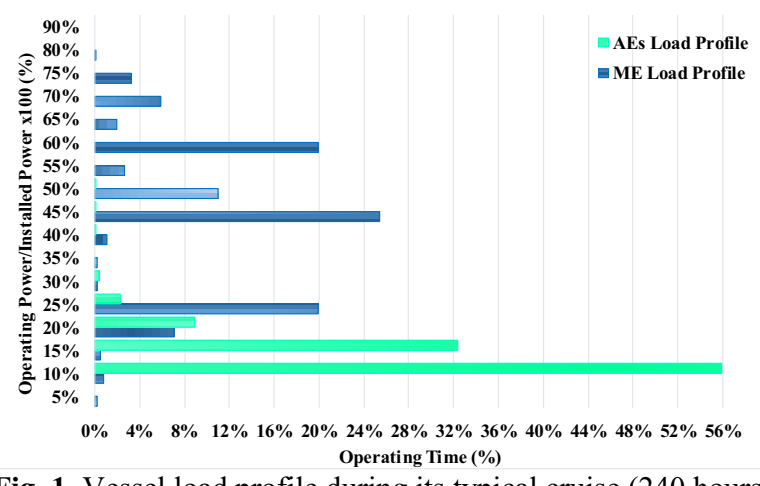

Fig. 1. Vessel load profile during its typical cruise (240 hours).

It is possible to notice that ME works at $45 \%$ of it nominal power capacity for $26 \%$ of the cruise duration, and it works at $75 \%$ for only $3 \%$ of the total time.

\section{Powertrain system based on $\mathrm{NH}_{3}$-SOFC technology}

Fig.2 illustrates the schematic concept of the proposed powertrain system based on $\mathrm{NH}_{3}$-SOFC technology. Ammonia, stored in liquid form, is vaporized and sent to the $\mathrm{SOFC}$, for the power generation. To regulate the voltage from the SOFC, a DC/DC converter is applied after the cell. A DC/AC inverter is considered, since the electric motor is supplied in AC. Downstream the AC switchboard, a transformer is needed, to supply the electric utilities according to the different type of load.

The electric power needed for the electric motor is regulated with a frequency converter, which allows to operate for the entire range of speeds. The electric motor is connected to the propeller shaft by means of a gearbox. The efficiencies of these components have not been considered in this analysis. 


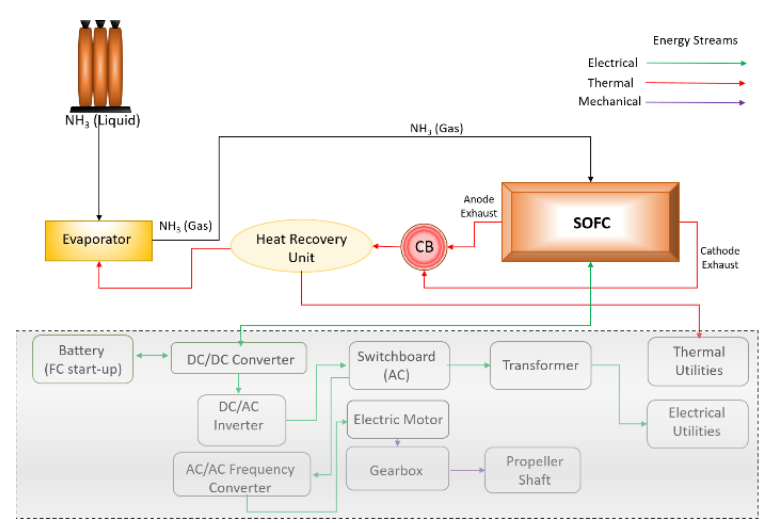

Fig. 2. Layout of $\mathrm{NH}_{3}-\mathrm{SOFC}$ based powertrain system.

To perform the feasibility replacement analysis, for the ammonia storage the cryogenic tank developed by Linde is taken into account [28] (Table 3).

Table 3. Ammonia ISO T50 storage tank characteristics [28]

\begin{tabular}{|l|c|}
\hline \multicolumn{1}{|c|}{ Technical data } & $\mathrm{LNH}_{3}$ \\
\hline External Diameter $(\mathrm{mm})$ & $2,500.0$ \\
\hline Length $(\mathrm{mm})$ & $4,480.0$ \\
\hline Empty Weight $(\mathrm{kg})$ & $11,500.0$ \\
\hline Internal Volume $\left(\mathrm{m}^{3}\right)$ & 22.0 \\
\hline
\end{tabular}

As far as the SOFC module is concerned, the $300 \mathrm{~kW}$ module developed by Bloom Energy is taken into account [29].

This module is designed to be fed by natural gas (nominal condition $56.9 \mathrm{~m}^{3} / \mathrm{h}$ ). Therefore, in this study we calculated the produced nominal electric power feeding the SOFC module with the same $\mathrm{NH}_{3}$ volumetric of natural gas $\left(56.9 \mathrm{~m}^{3} / \mathrm{h}\right)$, assuming the same conditions in terms of module volume and weight.

\subsection{System modeling}

The fuel cell power module and the BOP are modeled in Aspen Plus ${ }^{\mathrm{TM}}$ environment. Fig. 3 illustrates the flowsheet of the model. The ammonia, stored at $20^{\circ} \mathrm{C}$ and $8.8 \mathrm{bar}$, is vaporized (HE-1) and preheated (HE-2) by using the exhaust gasses (25) coming from the catalytic burner (B2). In the throttling valve (B9) the ammonia expands before entering the anode side of the fuel cell. The exhaust gasses, before being vented to the atmosphere, are used both to preheat (HE-3) the cathodic air (AIR) and to generate (HE4) steam for thermal loads onboard the vessel. In order to simulate the SOFC behavior from a thermodynamic point of view, the anode and the cathode are modeled by using some components, as suggested by the authors in a previous paper [30]. Table 4 describes these components.

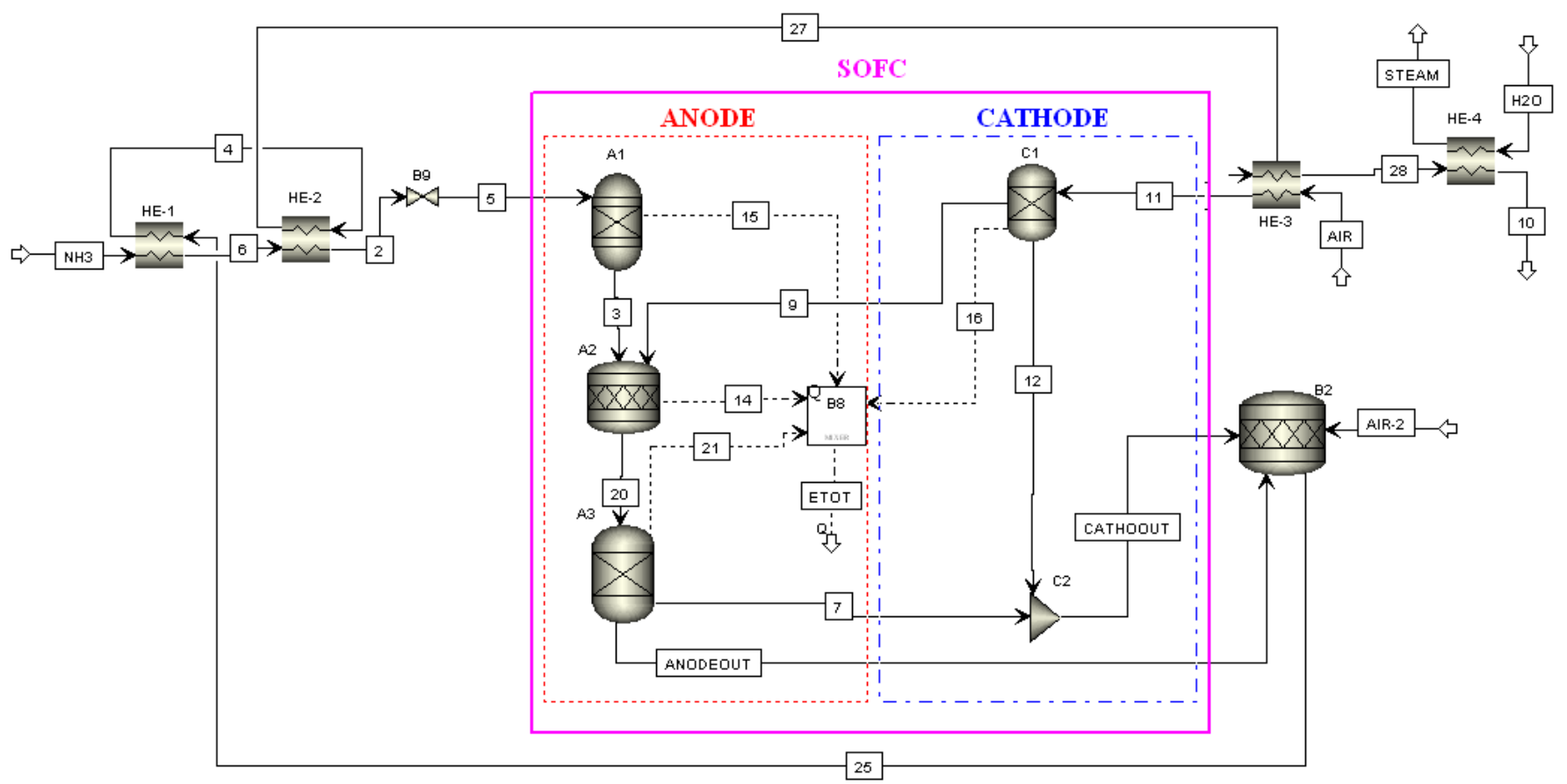

Fig. 3. $\mathrm{NH}_{3}-\mathrm{SOFC}$ system model adapted from [30] 
Table 4. Electrodes Modeling

\begin{tabular}{|l|l|}
\hline Electrode & \multicolumn{1}{|c|}{ Aspen Components } \\
\hline Anode & $\begin{array}{l}\text { Gibbs reactor (A1): in this reactor the } \\
\left.\text { ammonia cracking } \quad \text { (46kJ/mol } \mathrm{NH}_{3}\right) \\
\text { occurs: } \quad 2 \mathrm{NH}_{3} \rightarrow 3 \mathrm{H}_{2}+\mathrm{N}_{2} \\
\text { Stoichiometric reactor (A2): in this reactor } \\
\text { the hydrogen oxidation is carried out: } \\
\quad \mathrm{H}_{2}+\frac{1}{2} \mathrm{O}_{2} \rightarrow \mathrm{H}_{2} \mathrm{O}\end{array}$ \\
\hline Cathode & $\begin{array}{l}\text { Separator (A3): the unreacted oxygen is } \\
\text { separated to be again mixed to nitrogen. }\end{array}$ \\
$\begin{array}{l}\text { Separator (C1): the oxygen is separated by } \\
\text { nitrogen and sent to the anode side for } \\
\text { reacting with hydrogen } \\
\text { Mixer (C2): the unreacted oxygen is } \\
\text { mixed with the nitrogen to get the right } \\
\text { cathode off-gas composition. }\end{array}$ \\
\hline
\end{tabular}

The single cell polarization curve (Figure 4), implemented in a Fortran block calculator for estimating the fuel cell electrical performance, is taken from ref. [31]. Table 5 summarizes the fuel cell nominal operating data suggested in [31]. Finally, a thermal mixer block (B8) is used to solve the energy balance of the SOFC.

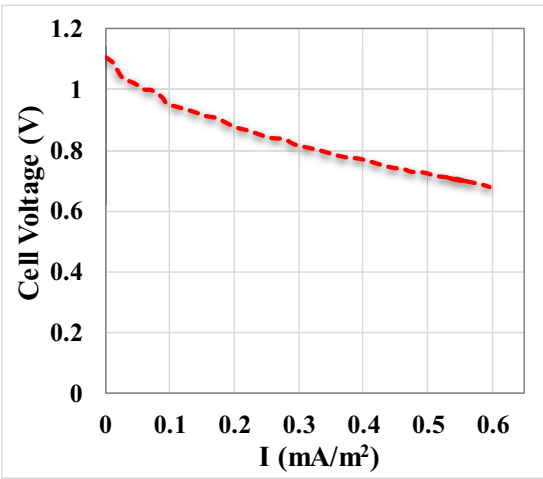

Fig. 4. NH3-SOFC module polarization curve

Table 5. $\mathrm{NH}_{3}-\mathrm{SOFC}$ module operating data [31]

\begin{tabular}{|c|c|}
\hline Active area $\left(\mathrm{cm}^{2}\right)$ & 500 \\
\hline Stacks Temperature $\left({ }^{\circ} \mathrm{C}\right)$ & 750 \\
\hline UF & 0.80 \\
\hline $\begin{array}{c}\text { Cell Voltage }(\mathrm{mV}) \\
\text { at nominal power }\end{array}$ & 714 \\
\hline $\begin{array}{c}\text { Current density }\left(\mathrm{mA} / \mathrm{cm}^{2}\right) \\
\text { at nominal power }\end{array}$ & 513 \\
\hline Cell electric power $(\mathrm{W})$ & 183 \\
\hline
\end{tabular}

\section{Results and discussion}

Results of the proposed analysis concern: i) the calculation of the $\mathrm{NH}_{3}$-SOFC module produced nominal electric power; ii) the assessment of the thermodynamic condition for the $\mathrm{NH}_{3}$-SOFC layout; iii) the feasibility of replacing the proposed system in terms of volume and weight for both the engine and fuel rooms.

\section{1 $\mathrm{NH}_{3}$-SOFC nominal electric power}

Taking into account the characteristics of the selected SOFC module, we calculated the produced nominal electric power feeding the SOFC module with the same $\mathrm{NH}_{3}$ volumetric of natural gas $\left(56.9 \mathrm{~m}^{3} / \mathrm{h}\right)$, assuming the same conditions in terms of module volume and weight. It results to be $118.3 \mathrm{~kW}$ instead of $300 \mathrm{~kW}$. Table 6 lists the main characteristics of the selected SOFC module.

Table 6. SOFC module characteristics [29]

\begin{tabular}{|l|c|}
\hline \multicolumn{1}{|c|}{ Technical data } & $\begin{array}{c}\text { Fuel Cell } \\
\text { Module }\end{array}$ \\
\hline Length $(\mathrm{m})$ & 7.8 \\
\hline Breadth $(\mathrm{m})$ & 2.6 \\
\hline Height $(\mathrm{m})$ & 2.3 \\
\hline Mass (tons) & 15.8 \\
\hline Nominal power- $\mathrm{NH}_{3}(\mathrm{~kW})$ & 118.3 \\
\hline
\end{tabular}

Taking into account these data, for sizing the SOFC system, we have assumed that the nominal power capacity of the SOFC powertrain matches the one of the reference main diesel engine (i.e., 8.3 MW). Consequently, the SOFC powertrain system is made up of $71 \times 118.3 \mathrm{~kW}$ units.

\subsection{Modeling results}

Starting from the performance of the single $\mathrm{NH}_{3}-\mathrm{SOFC}$ module, the thermodynamic conditions for each point of $\mathrm{NH}_{3}$-SOFC system are assessed. Results, referred to the nominal operating condition, are summarized in Table 7.

Table 7. Thermodynamic condition of $\mathrm{NH}_{3}-\mathrm{SOFC}$ system

\begin{tabular}{|c|c|c|c|c|}
\hline Flows & $\begin{array}{c}\text { Mass flow } \\
\text { rate (kg/s) }\end{array}$ & $\begin{array}{c}\mathrm{T} \\
\left({ }^{\circ} \mathrm{C}\right)\end{array}$ & $\begin{array}{c}\mathrm{P} \\
(\mathrm{bar})\end{array}$ & Composition \\
\hline $\mathrm{NH}_{3}$ & 0.86 & 20 & 8.8 & $\mathrm{NH}_{3}-100 \%$ \\
\hline 2 & 0.86 & 600 & 8.8 & $\mathrm{NH}_{3}-100 \%$ \\
\hline 3 & 0.86 & 750 & 1.1 & $\begin{array}{c}\mathrm{H}_{2}-75 \% \\
\mathrm{~N}_{2}-25 \%\end{array}$ \\
\hline 4 & 31.75 & 807 & 1.1 & $\begin{array}{c}\mathrm{N}_{2}-76.9 \% \\
\mathrm{O}_{2}-16.5 \%\end{array}$ \\
\hline 5 & 0.86 & 600 & 1.1 & $\mathrm{H}_{2} \mathrm{O}-6.6 \%$ \\
\hline 6 & 0.86 & 21 & 8.8 & $\mathrm{NH}_{3}-100 \%$ \\
\hline 7 & 6.08 & 750 & 1 & $\mathrm{NH}_{3}-100 \%$ \\
\hline 9 & 7.04 & 750 & 1.1 & $\mathrm{O}_{2}-100 \%$ \\
\hline $\mathrm{O}_{2}-100 \%$
\end{tabular}




\begin{tabular}{|c|c|c|c|c|}
\hline 10 & 31.75 & 152 & 1.1 & $\begin{array}{l}\mathrm{N}_{2}-76.9 \% \\
\mathrm{O}_{2}-16.5 \% \\
\mathrm{H}_{2} \mathrm{O}-6.6 \%\end{array}$ \\
\hline 11 & 30.24 & 650 & 1.1 & $\begin{array}{l}\mathrm{N}_{2}-79 \% \\
\mathrm{O}_{2}-21 \%\end{array}$ \\
\hline 12 & 23.20 & 750 & 1.1 & $\mathrm{~N}_{2}-100 \%$ \\
\hline 20 & 7.90 & 750 & 1.1 & $\begin{array}{c}\mathrm{O}_{2}-65.5 \%, \\
\mathrm{H}_{2} \mathrm{O}-20.7 \% \text {, } \\
\mathrm{N}_{2}-8.6 \% \\
\mathrm{H}_{2}-5.2 \%\end{array}$ \\
\hline 25 & 31.75 & 833.6 & 1.1 & $\begin{array}{c}\mathrm{N}_{2}-76.9 \%, \\
\mathrm{O}_{2}-16.5 \%, \\
\mathrm{H}_{2} \mathrm{O}-6.6 \%\end{array}$ \\
\hline 27 & 31.75 & 773.7 & 1.1 & $\begin{array}{c}\mathrm{N}_{2}-76.9 \%, \\
\mathrm{O}_{2}-16.5 \% \\
\mathrm{H}_{2} \mathrm{O}-6.6 \%\end{array}$ \\
\hline 28 & 31.75 & 215.7 & 1.1 & $\begin{array}{c}\mathrm{N}_{2}-76.9 \% \\
\mathrm{O}_{2}-16.5 \% \\
\mathrm{H}_{2} \mathrm{O}-6.6 \%\end{array}$ \\
\hline AIR & 30.24 & 20 & 1.1 & $\begin{array}{l}\mathrm{N}_{2}-79 \% \\
\mathrm{O}_{2}-21 \%\end{array}$ \\
\hline AIR-2 & 0.65 & 20 & 1.1 & $\begin{array}{l}\mathrm{N}_{2}-79 \% \\
\mathrm{O}_{2}-21 \%\end{array}$ \\
\hline $\begin{array}{c}\text { ANODE } \\
\text { OUT }\end{array}$ & 1.82 & 750 & 1.1 & $\begin{array}{c}\mathrm{N}_{2}-25 \% \\
\mathrm{H}_{2}-15 \% \\
\mathrm{H}_{2} \mathrm{O}-60 \%\end{array}$ \\
\hline $\begin{array}{c}\text { CATHODE } \\
\text { OUT }\end{array}$ & 29.28 & 750 & 1.1 & $\begin{array}{c}\mathrm{N}_{2}-81.3 \% \\
\mathrm{O}_{2}-18.7 \%\end{array}$ \\
\hline $\mathrm{H}_{2} \mathrm{O}$ & 0.49 & 20 & 1.1 & $\mathrm{H}_{2} \mathrm{O}-100 \%$ \\
\hline STEAM & 0.49 & 120 & 1.1 & $\mathrm{H}_{2} \mathrm{O}-100 \%$ \\
\hline
\end{tabular}

\subsection{Replacement Analysis}

The replacement analysis takes place by assessing the feasibility of installing the proposed system according to the available volume and the mass capacity of both the engine and fuel rooms. The weight and volume of the proposed propulsion system is assessed and compared with the ones of the diesel engine system (see Table 2). Taking into account the typical cruise performed by the selected vessel, the ammonia weight and volume needed to complete the journey are calculated and compared with the diesel.

\subsubsection{Technical feasibility: engine room}

The volume and the weight of each component of the proposed powertrain system are listed in Table 8 .
Table 8. Equipment Volume and Weight

\begin{tabular}{|l|c|c|}
\hline Equipment & $\begin{array}{c}\text { Volume } \\
\left(\mathrm{m}^{3}\right)\end{array}$ & $\begin{array}{c}\text { Weight } \\
\text { (tons) }\end{array}$ \\
\hline SOFC (71 modules)[29] & 3451.9 & 1121.8 \\
\hline Propulsion Motor [25] & 30 & 20 \\
\hline Converter [25] & 2.7 & 1 \\
\hline Inverter [25] & 4 & 2 \\
\hline $\begin{array}{l}\text { Variable Freq. Drive } \\
\text { (VFD) [25] }\end{array}$ & 31 & 8 \\
\hline Heat Exchangers & 27.1 & 19.2 \\
\hline BOP & 46.9 & 21.2 \\
\hline Total & 3581.2 & 1183.7 \\
\hline
\end{tabular}

Comparing the results of tables 2-8, it can be noticed that the $\mathrm{NH}_{3}$-SOFC powertrain system occupies approximately a space 22 fold-higher with respect to the diesel engine, and exceeds the available volume of the engine room of about $9 \%$. As far as the weight is concerned, the proposed system overcomes the weight of the diesel engine system of about $91 \%$.

\subsubsection{Technical feasibility: fuel room}

In order to perform the feasibility replacement analysis in the fuel room, it is needed to calculate the ammonia consumption for the considered cruise.

The ammonia consumption $\left(\mathrm{C}_{\mathrm{NH}_{3}}\right)$ in each load condition (i) has been calculated as reported in [32]:

$$
C_{\mathrm{NH}_{3}}(i)=\frac{L_{f}(i) \cdot W_{S O F C}}{L H V_{\mathrm{NH}_{3}} \cdot \eta(i)}
$$

where, $W_{S O F C}$ is the nominal power of the SOFC system, $L_{f}$ is the load factor of the chemical tanker (Fig. 2), $\mathrm{LHV}_{\mathrm{NH}_{3}}$ represents the ammonia lower heating value (18.8 $\mathrm{MJ} / \mathrm{kg}$ ), and $\eta$ is the SOFC efficiency (Fig.3).

Therefore, considering the fuel cell operation during the cruise (240 hours), the total ammonia consumption $\left(\mathrm{TC}_{\mathrm{NH}_{3}}\right)$ has been calculated as:

$$
T C_{N_{3}}=\int_{0}^{t_{f}} \frac{L_{f}(i) \cdot W_{S O F C}}{L H V_{N H_{3}} \cdot \eta(i)} d t
$$

Taking into to account Eqs. 3-4, the overall ammonia consumption during the cruise is 240.2 tons. By assuming a fuel margin percentage of $10 \%$ for safety conditions, the needed ammonia amount to be stored on-board is 264.2 tons.

Considering the weight and the volume of the ammonia storage tanks (see table 3) the total volume and weight of stored ammonia is calculated. Fig.5 compares the weight and volume of the ammonia with the diesel, needed for the selected cruise. 


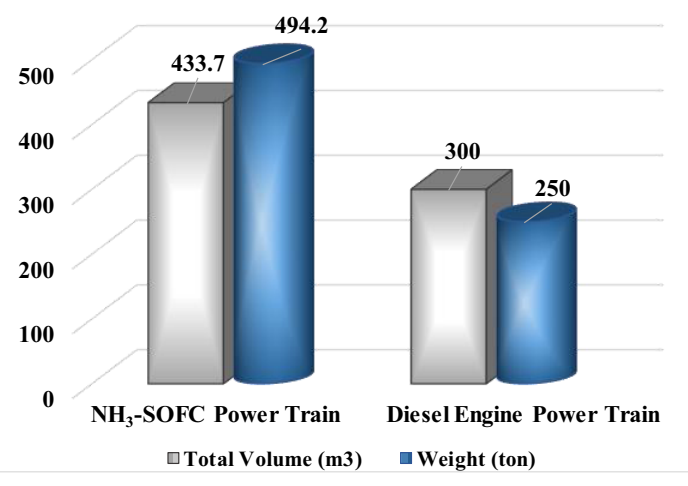

Fig. 5. $\mathrm{NH}_{3}$-diesel weight and volume comparison

It can be noticed that, even if the volume of stored ammonia is 1.4 times higher with respect to the diesel, it is in accordance with the available volume in the fuel room. The weight of the storage technology represents the critical issue since, even if the ammonia consumption is quite similar to the diesel one ( 264.2 tons vs 250 tons), the storage technology involves a weight increase of about $49 \%$ (494.2 tons vs 250 tons).

Therefore, considering the weight increasing both in the engine room and in the fuel room, for installing the proposed system on board the vessel, a cargo reduction is needed. In particular, it has been calculated a cargo reduction of about $2.88 \%$.

\section{Powertrain Systems Comparison}

Fig.6 compares the $\mathrm{NH}_{3}$-SOFC system with the diesel one in terms of weight incidence of the equipment.

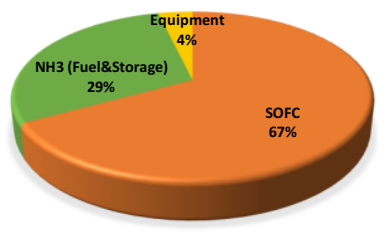

(a)

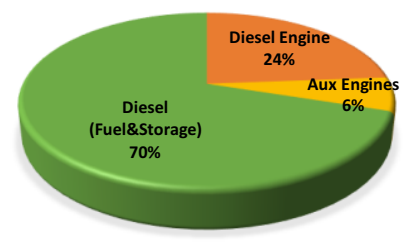

(b)
Fig. 6. $\mathrm{NH}_{3}$-diesel weight incidence equipment comparison

It is worth noticing the greatest incidence of the SOFC weight $(67 \%)$ with respect to the diesel engine system (24\%), which represents the most critical issue for the cargo reduction.

\section{Conclusion}

In this paper the feasibility analysis for the integration of a solid oxide fuel cells fed by ammonia as propulsion system on-bard a commercial vessel, is carried out.

The $\mathrm{NH}_{3}$ based-SOFC system is designed to completely replace the main diesel engine as well as the auxiliary engines, with 71 units of $118 \mathrm{~kW}$ each.

The results show that the proposed system occupies a space in the engine room 22 time higher with respect to the diesel engine, and exceeds the available volume of the engine room of about $9 \%$. In terms of weight, the $\mathrm{NH}_{3}$
based-SOFC system overcomes the weight of the diesel engine system of about $91 \%$.

The volume of stored ammonia is 1.4 times higher with respect to the diesel but it is consistent with the available volume in the fuel room. The critical issue is represented by the weight of the storage technology. As matter of fact, even if the ammonia consumption is quite similar to the diesel one (264.2 tons vs 250 tons), the storage technology involves a weight increase of about $49 \%$ (494.2 tons vs 250 tons).

Therefore, taking into account the weight increasing both in the engine room and in the fuel room, installing the proposed system on board the commercial vessel, requires a cargo reduction of about $2.88 \%$.

\section{References}

1. S. De Bruyn, M. Bijleveld, L. de Graaff, E. Schep, A. Schroten, R. Vergeer, and S. Ahdour, CE Delft 175 (2018)

2. K. Anderson and G. Peters, Science (80-. ). 354, $182(2016)$

3. K. Y. Bjerkan and H. Seter, Transp. Res. Part D Transp. Environ. 72, 243 (2019)

4. D. Rutherford and B. Comer, Int. Counc. Clean Transp. 8 (2018)

5. E. A. Bouman, E. Lindstad, A. I. Rialland, and A. H. Strømman, Transp. Res. Part D Transp. Environ. 52, 408 (2017)

6. S. Integration, H. Rail, and M. Applications, (2020)

7. S. Karimi, M. Zadeh, and J. A. Suul, IEEE Electrif. Mag. 8, 47 (2020)

8. A. Ritari, J. Huotari, J. Halme, and K. Tammi, Energy (2020)

9. H. Bach, A. Bergek, Ø. Bjørgum, T. Hansen, A. Kenzhegaliyeva, and M. Steen, Transp. Res. Part D Transp. Environ. 87, 102492 (2020)

10. A. Bergek, Ø. Bjørgum, T. Hansen, J. Hanson, and M. Steen, 9th Int. Sustain. Transitions Conf. $1(2018)$

11. X. Mao, D. Rutherford, L. Osipova, and B. Comer, (2020)

12. A. E. Georgeff, X. Mao, D. Rutherford, D. Ph, L. Osipova, and D. Ph, (2020)

13. Fuel Cells Bull. 2008, 4 (2008)

14. L. K. C. Tse, S. Wilkins, and R. F. Martinezbotas, EET-2007 Eur. Ele-Drive Conf. (2007)

15. (2016)

16. C. Dall'Armi, D. Micheli, and R. Taccani, Int. J. Hydrogen Energy 46, 13878 (2021)

17. S. Di Micco, M. Minutillo, and A. Forcina, E3S Web Conf. 312, (2021)

18. C. Strazza, A. Del Borghi, P. Costamagna, A. Traverso, and M. Santin, Appl. Energy 87, 1670 (2010)

19. M. Gianni, A. Pietra, and R. Taccani, E3S Web Conf. 238, 1 (2021)

20. M. C. Díaz-de-Baldasano, F. J. Mateos, L. R. Núñez-Rivas, and T. J. Leo, Appl. Energy 116, 91 (2014) 
21. A. Haseltalab, L. van Biert, H. Sapra, B. Mestemaker, and R. R. Negenborn, Energy Convers. Manag. 245, 114625 (2021)

22. L. Starcrest Consulting Group, Long Beach, CA (2019)

23. L. Starcrest Consulting Group, Port of Los Angeles 2019 Air Emissions Inventory. Los Angeles, CA 2019 (2019)

24. Marine Traffic: Global Ship tracking Intelligence.

25. K. Kim, G. Roh, W. Kim, and K. Chun, J. Mar. Sci. Eng. (2020)

26. MAN Diesel \& Turbo, Marine Engine Programme (2020)
27. Wärtsilä Generating Sets. Available online., (2021)

28. The Linde Group datasheet-01-ammonia-June2017_tcm17-417364, Datasheet

29. Bloom Energy Energy Server 5 PRODUCT DATASHEET Always On

30. A. Perna, M. Minutillo, and E. Jannelli, Energy Convers. Manag. 159, 381 (2018)

31. A. Perna, M. Minutillo, E. Jannelli, V. Cigolotti, S. W. Nam, and J. Han, Appl. Energy 231, 1216 (2018)

32. C. Raucci, T. Smith, and P. Dodds, The Potential of Hydrogen to Fuel International Shipping, 2017 